\title{
Silage from heart-of-palm waste produced from Alexander palm tree ${ }^{\mathfrak{a}}$
}

\author{
Ensilaje de residuos de palmito producidos a partir de Palma Real
}

Silagem de resíduos de palmito produzidos a partir da Palmeira Real

Geraldo F V Bayão ${ }^{1 *}$, Zoot, PhD; Augusto C Queiroz², EA, PhD; Róberson M Pimentel ${ }^{3}$ Zoot, DSc; Samuel G Freitas ${ }^{2}$, Zoot, MSc; Katiene R S Sousa ${ }^{4}$, MV, DSc; Lucas L Cardoso ${ }^{2}$, Zoot, DSc; Marcos I Marcondes ${ }^{2}$, Zoot, DSc; Camila D A Batalha ${ }^{5}$, Zoot, DSc; Gabriel B Oliveira ${ }^{6}$, Biol, DSc; Tadeu E Silva ${ }^{2}$, Zoot, MSc.

${ }^{1}$ Instituto Federal de Educação, Ciência e Tecnologia do Maranhão, São Luís, MA, Brazil.

${ }^{2}$ Universidade Federal de Viçosa, Departamento de Zootecnia, Viçosa, MG, Brazil.

${ }^{3}$ Universidade Federal Fluminense, Departamento de Zootecnia, Niterói, RJ, Brazil.

${ }^{4}$ Universidade Federal do Maranhão, Centro de Ciências Agrárias e Ambientais, Chapadinha, MA, Brazil.

${ }^{5}$ Escola Superior de agricultura Luiz de Queiroz, USP, Piracicaba, SP, Brazil.

${ }^{6}$ Universidade Federal de Minas Gerais, Belo Horizonte, MG, Brazil.

(Received: October 26, 2016; accepted: April 10, 2018)

doi: 10.17533/udea.rccp.v32n1a08

\begin{abstract}
Background: Production of heart-of-palm from Alexander palm tree generates a waste that could be used as silage for feeding ruminants. Objective: To evaluate the chemical composition, fermentation parameters, and quality of silage made from waste of heart-of-palm production using Alexander palm. Methods: Three types of silage made from waste of heart-of-palm production were evaluated: 1) leaf silage, 2) sheath silage, and 3) compound (leaf + sheath) silage. The processed waste was packed in experimental silos and distributed in a completely randomized design with 10 replications. Means were compared pairwise using Tukey's test at the 5\% significance level. Results: Leaf silage had the highest $\mathrm{pH}(\mathrm{p}<0.05)$ and the lowest ammonia nitrogen $(p<0.05)$ in relation to the other silages. No difference was observed $(p>0.05)$ for lactic and butyric acids, whereas acetic acid was higher $(\mathrm{p}<0.05)$ in the sheath and compound silages. Dry matter and crude protein contents were the highest $(p<0.05)$ in leaf silage. Neutral detergent fiber was higher $(p<0.05)$ in sheath silage,
\end{abstract}

a. To cite this article: Bayão GFV, Queiroz AC, Pimentel RM, Freitas SG, Sousa KRS, Cardoso LL, Marcondes MI, Batalha CDA, Oliveira GB, Silva TE. Silage from heart-of-palm waste produced from Alexander palm tree. Rev Colomb Cienc Pecu 2019; 32(1):64-70.

* Corresponding author: Geraldo Fábio Viana Bayão. Instituto Federal de Educação, Ciência e Tecnologia do Maranhão, Campus Maracanã, Avenida dos Curiós, s/n, Bairro Vila Esperança, São Luís - MA, CEP 65095-460, Brazil. Tel.: 9898810 7414. E-mail: geraldo.bayao@ifma.edu.br 
followed by leaf and compound silages, respectively. The highest lignin content $(p<0.05)$ was observed in sheath silage. Conclusions: Based on the fermentative parameters, waste from heart-of-palm from Alexander palm tree has potential for silage production. However, differences in silage composition at the time of feeding ruminants should be considered.

Keywords: Archontophoenix alexandrae, byproduct, fermentation, forage, organic acid, $\mathrm{pH}$.

\section{Resumen}

Antecedentes: Los residuos de la producción de palmito de Palma Real podrian utilizarse como ensilaje para alimentación de rumiantes. Objetivo: Determinar la composición, parámetros químicos de fermentación, y calidad del ensilaje elaborado a partir de residuos procedentes de la producción de palmito de Palma Real. Métodos: Tres tipos de ensilaje hechos con los residuos generados a partir de la producción de palmito fueron evaluados: 1) ensilaje de hojas, 2) ensilaje de vainas, y 3) ensilaje compuesto (hojas + vainas). Los residuos tratados fueron empacados en silos experimentales y distribuidos en un diseño completamente al azar con 10 repeticiones. Las medias fueron comparadas mediante la prueba de Tukey, con un nivel de significancia del 5\%. Resultados: El ensilaje de hojas mostró el $\mathrm{pH}$ más alto $(\mathrm{p}<0,05)$ y el nivel más bajo de nitrógeno amoniacal $(\mathrm{p}<0,05)$ en comparación con los otros ensilajes. No se observaron diferencias $(\mathrm{p}>0,05)$ en los ácidos láctico y butírico, mientras que el ácido acético fue mayor en el ensilaje de vainas y en el compuesto en relación con el otro ensilaje. La materia seca (MS) y el contenido de proteína cruda (PC) fueron mayores $(\mathrm{p}<0,05)$ en el ensilaje de hojas. Los contenidos de fibra detergente neutra fueron mayores $(p<0,05)$ en los ensilajes de vainas, seguido por los ensilajes de hojas y compuesto, respectivamente. El contenido de lignina fue más alto $(\mathrm{p}<0,05)$ en el ensilaje de vainas. Conclusiones: Según los parámetros fermentativos, los residuos de la producción de palmito de Palma Real tienen potencial para la producción de ensilaje. Sin embargo, se deben considerar las diferencias en la composición de los ensilajes al momento de alimentar rumiantes.

Palabras clave: ácidos orgánicos, Archontophoenix alexandrae, fermentación, forraje, $\mathrm{pH}$, subproductos.

\section{Resumo}

Antecedentes: Resíduos da produção de palmito da palmeira Real são um problema para a agroindústria devido sua falta de utilização e o seu uso na forma de silagem pode ser uma alternativa na alimentação de ruminantes. Objetivo: Avaliar a composição química e os parâmetros fermentativos, e verificar a qualidade da silagem produzida a partir do resíduo da produção de palmito da Palmeira Real Australiana. Métodos: Foram avaliadas três tipos de silagem de resíduo da produção de palmito da Palmeira Real: silagem de folha, silagem de bainha e silagem da composta (folha + bainha). O resíduo processado foi acondicionado em silos experimentais e distribuídos em um delineamento inteiramente casualizado com 10 repetições e as médias comparadas pelo teste de Tukey a 5\% de significância. Resultados: A silagem de folha apresentou maior $\mathrm{pH}$ $(p<0,05)$ em relação as demais silagens, enquanto para o nitrogênio amoniacal $(p<0,05)$, apresentou menor teor em relação as demais silagens. Não observou-se diferença $(p>0,05)$ para os ácidos lático e butírico, enquanto o ácido acético foi maior para as silagens de bainha e composta em relação as demais silagens. $O$ teor de matéria seca $(\mathrm{MS})$, proteína bruta $(\mathrm{PB})$ foi maior $(\mathrm{p}<0,05)$ na silagem de folha em relação as demais silagens. A fibra em detergente neutro analisada estimada apresentou maiores valores $(p<0,05)$ para a silagem de bainha, seguida pela silagem de folhas e silagem composta, respectivamente. $\mathrm{O}$ teor de lignina foi maior $(p<0,05)$ para a silagem de bainha. Conclusões: De acordo com os parâmetros fermentativos, os resíduos da produção de palmito da Palmeira Real apresentam potencial para a produção de silagem. No entanto, as diferenças na composição das silagens devem ser consideradas quando oferecidas para animais ruminantes.

Palavras-chave: ácidos orgânicos, Archontophoenix alexandrae, fermentação, forragem, subprodutos, $p H$.

\section{Introduction}

World production of heart of palm has shifted from extractive to cultivated due to current extraction prohibition in many forests, consumer market demands for sustainable products, and reduction of natural palm reserves. Some species have been cultivated to explore its economic feasibility and to avoid possible 
extinction of some species, as is the case of Alexander palm (Archontophoenix alexandrae).

There are approximately 39 palm tree species in the Atlantic forest, in which Juçara (Euterpe edulis; Fermino et al., 2014), açaí (Euterpe oleracea), and pupunha (Bactris gasipaes) species stand out for the production of heart of palm. To exploit heart of palm, however, the palm tree must be cut down to extract the material. Processing of the Alexander palm for heart-of-palm production discards the leaves, sheath, and part of the stems, which are considered waste without commercial value for the agroindustry (Bayão et al., 2014). One plant yields approximately $0.4 \mathrm{~kg}$ of commercial heart of palm and generates approximately $13 \mathrm{~kg}$ of waste, including leaves, stems, and sheaths (Fermino et al., 2014), corresponding to $96.9 \%$ of waste per plant. In addition, the waste is a source of contamination.

Degradation of the organic wastes depends on factors such as the carbon/nitrogen ratio, physicochemical and biological characteristics, and temperature and moisture of the soil (Figueiredo et al., 2012). Because of the difficulty of degradation, areas in the production sites are used to store waste that could be used for other purposes.

Therefore, the use of waste from heart-of-palm production in ruminant feeding could be an alternative to discarding waste in the environment, representing an economic advantage because the waste is low cost and could be used as a fiber source for ruminants (Bayão et al., 2014).

Given that the waste from heart-of-palm production from the Alexander palm has high lignin and low protein content, this study was undertaken to evaluate the chemical composition, fermentation parameters, and quality of its silage.

\section{Materials and methods}

\section{Ethical considerations}

All procedures were conducted in accordance with the guidelines of the Brazilian College of Animal Experimentation (Code of Practice for the Care and
Use of Animals for Experimental Purposes) and were reviewed and approved by the Ethics Committee on Use of Animals for Research of the Federal University of Viçosa. The project and registration numbers are 166682 and 50448459244, respectively.

\section{Location}

The experiment was conducted in the Animal Nutrition Laboratory of the Department of Animal Science at the Federal University of Viçosa (UFV), located in Viçosa, Minas Gerais, Brazil.

The waste from heart-of-palm production of Alexander palm used in this study was provided by the Real Palm ${ }^{\circledR}$ canned heart-of-palm industry located in Cajuri, Minas Gerais, Brazil.

\section{Residue silage preparation}

The waste consisted of the sheaths that surround the heart of palm, and the palm tree leaves. Three types of silage were used: leaf silage, sheath silage, and compound (leaf + sheath) silage. The compound silage was formulated proportionally according to the average percentage of leaves and sheaths present in an Alexander palm tree, $453.0 \mathrm{~g} / \mathrm{kg}$ and $547.0 \mathrm{~g} / \mathrm{kg}$, respectively, on a natural matter basis.

The waste was processed using a knife mill (Cremasco, Itapira, SP, Brazil) to a theoretical particle size of 2 to $3 \mathrm{~cm}$ and packed in 30 experimental polyvinyl chloride $(\mathrm{PVC})$ silos $(5 \mathrm{~cm}$ diameter $\times 50$ $\mathrm{cm}$ length), equipped with Bunsen valves to allow the escape of fermentation gases. The roughage was compacted manually to reach a fixed density between $450 \mathrm{~kg} / \mathrm{m}^{3}$ and $600 \mathrm{~kg} / \mathrm{m}^{3}$ of natural matter. Waste samples were collected to determine the chemical composition before ensiling (Table 1).

\section{Chemical analyses and fermentation parameters}

After 40 days of storage, silos were opened and the silage was weighed, deteriorated parts were discarded, the content was homogenized, and samples were collected for analyses.

For the evaluation of $\mathrm{pH}$, ammonia nitrogen, and fatty acids from fermentation (lactate, acetate, 
propionate, and butyrate), $10 \mathrm{~g}$ silage samples were collected after silo opening. Samples were diluted in $90 \mathrm{~mL}$ distilled water, homogenized in an industrial blender (Metvisa, Brusque, SC, Brazil) for $1 \mathrm{~min}$, and filtered through a fine sieve. Afterwards, the $\mathrm{pH}$ of this solution was measured. Ammonia nitrogen in the extract filtrate was analyzed using a distiller with a Kjeldahl-type condenser (Tecnal - TE 0364, Piraciaba, SP, Brazil), (Method - 1.6R, AFIA), following Cunniff (1995) methodology. An aliquot of the filtrate extract prepared from a chopped silage sample was used for determination of ammonia nitrogen concentration through distillation and titration, where the ammonium ion was converted back to ammonia, and the titrant volume was recorded for calculation of the result. One milliliter of a $20 \%$ metaphosphoric acid solution was added to $2 \mathrm{~mL}$ of this filtrate and the solution was centrifuged at 3,000 rpm for 15 min, and then organic acids were determined by high-performance liquid chromatography (HPLC) following the recommendations of Wilson (1971).

Fresh and ensiled waste samples were dried in a forced-air oven $\left(65^{\circ} \mathrm{C} / 72 \mathrm{~h}\right.$; Marconi - MA035/1152, Piracicaba, SP, Brazil), ground through a knife mill (1 mm; Solab - SL32, Piracicaba, SP, Brazil), packed in plastic containers, and subsequently the dry matter (DM) contents (Method 967.03 - AOAC, 1990), crude protein (CP) (Method 981.10 - AOAC, 1990), and ether extract (EE) (Method 920.29 - AOAC, 1990) were evaluated. To determine the neutral detergent fiber (NDF) and acid detergent fiber (ADF) contents, the methodology of Van Soest et al. (1994) was used with the modifications proposed in the Ankon device manual (Ankon Technology Corporation, Macedon, New York, US). Corrections of NDF and ADF for ash and protein (ap) were performed according to Mertens (2002) and Licitra et al. (1996), respectively. Acid detergent lignin (ADL) was determined according to method 973.18 (AOAC, 2002), in which the vADF residue was treated with $72 \%$ sulfuric acid. Nonfibrous carbohydrates (NFC) were calculated using the equation $\mathrm{NFC}=\mathrm{OM}-(\mathrm{NDF} c p+\mathrm{CP}+\mathrm{EE})$, where $\mathrm{OM}$ $=$ organic matter and NDFap $=$ neutral detergent fiber.

The analysis of indigestible neutral detergent fiber (iNDF) was obtained after in situ incubation in triplicate inside non-woven fabric bags ["TNT", $100 \mathrm{~g}$ $\mathrm{m}^{-2}$ for $240 \mathrm{~h}$ in a bovine rumen (Casali et al., 2008).
Afterwards, the NDF was analyzed following Mertens (2002) to quantify the iNDF content.

\section{Experimental design and statistical analyses}

A completely randomized experimental design was used, with 10 replicates for each of the three treatments, totaling 30 experimental silos. The experimental model was:

$$
\mathrm{Y}_{i j}=\mu+\tau_{i}+\varepsilon_{i j}
$$

Where:

$\mathrm{Y}_{i j}=$ experimental response that received treatment $i$ in replicate $j$.

$$
\begin{aligned}
\mu & =\text { overall constant. } \\
\tau_{i} & =\text { effect of treatment } \mathrm{i} \text { (waste). } \\
\varepsilon_{i j} & =\text { experimental error. }
\end{aligned}
$$

Data were analyzed using $S A S^{\circledR}$ software version 9.2 (SAS Institute Inc., Cary, NC, USA, 2008), and means were compared by Tukey's test at $5 \%$ significance.

\section{Results}

The composition of the residues in the natural material is shown in Table 1.

Table 1. Chemical composition of wastes from heart-of-palm production using Alexander palms in natura.

\begin{tabular}{lccc}
\hline \multicolumn{1}{c}{ Variable } & Leaf & Sheath & Compound \\
\hline Dry matter & 307.1 & 203.4 & 201.1 \\
Organic matter $^{1}$ & 948.3 & 951.1 & 960.4 \\
Crude protein $^{1}$ & 76.4 & 31.2 & 51.4 \\
Ether extract $^{1}$ & 7.2 & 2.9 & 6.3 \\
Non-fiber carbohydrates $^{1}$ & 157.9 & 164.2 & 198.1 \\
Neutral detergent fiber (ap) $^{1}$ & 707.1 & 753.9 & 704.1 \\
Acid detergent fiber (ap) $^{1}$ & 467.5 & 479.2 & 442.3 \\
Lignin $^{1}$ & 106.4 & 122.8 & 114.3 \\
Neutral detergent insoluble $^{1}$ & 272.3 & 206.7 & 243.6 \\
protein $^{2}$ & & & \\
Acid detergent insoluble protein $^{2}$ & 155.1 & 129.2 & 140.2 \\
\hline
\end{tabular}

${ }^{1} \mathrm{~g} / \mathrm{kg}$ of dry matter; ${ }^{2}$ Percentage of crude protein; ap = corrected for ash and protein. 
Crude protein content was higher for leaf silage, followed by compound and then sheath silage $(\mathrm{p}<0.05$; Table 2). Both neutral detergent insoluble protein and acid detergent insoluble protein (ADIP) were higher in the sheath silage, followed by the compound and then leaf silage (Table 2). The NDF and iNDF contents were higher for sheath silage (Table 2). There was no difference $(p>0.05)$ between lignin content of the leaf and compound silages; however, both were lower $(\mathrm{p}<0.05)$ than sheath silage (Table 2$)$.

The highest $\mathrm{pH}$ value $(\mathrm{p}<0.05)$ was observed in the leaf silage, whereas that of the compound and sheath silages did not differ $(p>0.05)$ (Table 3$)$.
The lowest values $(\mathrm{p}<0.05)$ for ammonia nitrogen were in the leaf silage, followed by the compound and then the sheath silage (Table 3). No statistical difference was observed $(\mathrm{p}>0.05)$ in the concentration of lactic acid between silages (Table 3 ), although the concentration of lactic acid was higher in relation to the other acids originating from fermentation. No difference was detected $(p>0.05)$ for acetic acid content in the sheath and compound silage; however, their values were higher $(p<0.05)$ than that of leaf silage (Table 3 ). The concentration of butyric acid was not statistically different $(\mathrm{p}>0.05)$ between the three waste silages, with values lower than $0.5 \mathrm{~g} / \mathrm{kg}$ in all three (Table 3).

Table 2. Chemical composition of silages from heart-of-palm waste using Alexander palm.

\begin{tabular}{|c|c|c|c|c|c|c|c|c|}
\hline \multirow[t]{2}{*}{ Variable } & \multicolumn{5}{|c|}{ Waste } & \multirow[b]{2}{*}{ Compound } & \multirow[b]{2}{*}{ SEM } & \multirow[b]{2}{*}{$p$ value } \\
\hline & & Leaf & SEM & Sheath & SEM & & & \\
\hline Dry matter & $411.1^{\mathrm{a}}$ & \pm 0.09 & $361.4^{b}$ & \pm 0.16 & $353.9^{c}$ & \pm 0.10 & $<0.01$ & \\
\hline Organic matter ${ }^{1}$ & $936.1^{\mathrm{c}}$ & \pm 0.07 & $956.5^{\mathrm{a}}$ & \pm 0.09 & $946.2^{b}$ & \pm 0.09 & $<0.01$ & \\
\hline Crude protein ${ }^{1}$ & $93.1^{\mathrm{a}}$ & \pm 0.06 & $37.2^{c}$ & \pm 0.05 & $67.4^{\mathrm{b}}$ & \pm 0.07 & $<0.01$ & \\
\hline Ether extract ${ }^{1}$ & $14.6^{\mathrm{a}}$ & \pm 0.022 & $4.8^{\mathrm{c}}$ & \pm 0.004 & $10.3^{b}$ & \pm 0.005 & $<0.01$ & \\
\hline Non-fiber carbohydrates ${ }^{1}$ & $116.4^{\mathrm{c}}$ & \pm 0.14 & $124.7^{\mathrm{b}}$ & \pm 0.24 & $186.7^{a}$ & \pm 0.20 & $<0.01$ & \\
\hline Neutral detergent fiber $(a p)^{1}$ & $712.3^{b}$ & \pm 0.10 & $789.1^{\mathrm{a}}$ & \pm 0.12 & $681.6^{c}$ & \pm 0.22 & $<0.01$ & \\
\hline Acid detergent fiber $(a p)^{1}$ & $465.3^{b}$ & \pm 0.24 & $494.8^{a}$ & \pm 0.36 & $432.9^{c}$ & \pm 0.25 & $<0.01$ & \\
\hline Lignin $^{1}$ & $109.0^{\mathrm{b}}$ & \pm 0.15 & $127.2^{\mathrm{a}}$ & \pm 0.11 & $114.3^{b}$ & \pm 0.15 & $<0.01$ & \\
\hline Indigestible neutral detergent fiber ${ }^{1}$ & $324.1^{\mathrm{c}}$ & \pm 0.17 & $408.1^{\mathrm{a}}$ & \pm 0.20 & $384.3^{b}$ & \pm 0.23 & $<0.01$ & \\
\hline Neutral detergent insoluble protein ${ }^{2}$ & $329.0^{c}$ & \pm 0.21 & $407.1^{\mathrm{a}}$ & \pm 0.19 & $389.2^{b}$ & \pm 0.40 & $<0.01$ & \\
\hline Acid detergent insoluble protein ${ }^{2}$ & $227.2^{\mathrm{c}}$ & \pm 0.16 & $284.6^{a}$ & \pm 0.09 & $251.0^{\mathrm{b}}$ & \pm 0.14 & $<0.01$ & \\
\hline
\end{tabular}

${ }^{1} \mathrm{~g} / \mathrm{kg}$ of dry matter; ${ }^{2} \mathrm{~g} / \mathrm{kg}$ of crude protein; ap = corrected for ash and protein.

Means followed by different superscript letters (a, b, c ) within the same row are significantly different $(p<0.05)$ by Tukey's test.

Table 3. Qualitative characteristics of silages from heart-of-palm waste using Alexander palm.

\begin{tabular}{|c|c|c|c|c|c|c|c|}
\hline \multirow[t]{2}{*}{ Variable } & \multicolumn{5}{|c|}{ Waste } & \multirow[b]{2}{*}{ SEM } & \multirow[b]{2}{*}{ p-value } \\
\hline & Leaf & SEM & Sheath & SEM & Compound & & \\
\hline $\mathrm{pH}$ & $4.3^{a}$ & \pm 0.04 & $3.6^{b}$ & \pm 0.08 & $3.6^{\mathrm{b}}$ & \pm 0.02 & $<0.01$ \\
\hline Ammonia $\left(\mathrm{NH}_{3}\right)^{2}$ & $10.3^{c}$ & \pm 0.001 & $47.4^{\mathrm{a}}$ & \pm 0.001 & $17.9^{\mathrm{b}}$ & \pm 0.001 & $<0.01$ \\
\hline Lactic acid $^{1}$ & 37.6 & \pm 0.60 & 48.4 & \pm 0.51 & 55.1 & \pm 0.48 & 0.0947 \\
\hline Acetic acid ${ }^{1}$ & $26.8^{b}$ & \pm 0.33 & $42.3^{a}$ & \pm 0.57 & $46.8^{a}$ & \pm 0.34 & 0.0094 \\
\hline Propionic acid ${ }^{1}$ & $13.2^{\mathrm{b}}$ & \pm 0.07 & $16.4^{\mathrm{b}}$ & \pm 0.14 & $22.2^{\mathrm{a}}$ & \pm 0.16 & 0.0002 \\
\hline Butyric acid ${ }^{1}$ & 0.39 & \pm 0.002 & 0.43 & \pm 0.002 & 0.37 & \pm 0.002 & 0.1209 \\
\hline
\end{tabular}

Means followed by different superscript letters $(a, b, c)$ within the same row are significantly different $(p<0.05)$ by Tukey's test.

${ }^{1} \mathrm{~g} / \mathrm{kg}$ of dry matter; ${ }^{2} \mathrm{~g} / \mathrm{kg}$ of total nitrogen. 


\section{Discussion}

According to Jobim et al. (2009), the DM content of an ensiled plant forage should be between 280.0 and $400.0 \mathrm{~g} / \mathrm{kg}$. Values below this range could impair silage quality due to growth of microorganisms that compromise quality and promote effluent losses. Thus, the sheath and compound wastes had DM contents that could compromise silage quality (Table 1), although the concentration of water-soluble carbohydrates also influences fermentation (Santos et al., 2006). However, these variables were not evaluated in the present study.

Comparing DM contents of the fresh material (Table 1) to the contents of their respective silage (Table 2) we observed an increase in DM content in silage, which may be related to effluent losses occurring during fermentation, although this variable was not estimated in the present study.

Alexander palm leaves, and consequently leaf silage, have higher CP content than that of the sheath (Tables 1 and 2). Likewise, because the compound silage included leaves, it also had greater $\mathrm{CP}$ levels in relation to the sheath silage. In an experiment with enriched wilted peach palm silage, Oliveira et al. (2010) found $45.0 \mathrm{~g} / \mathrm{kg}$ average CP content, whereas Schmidt et al. (2010) found 46.0 $\mathrm{g} / \mathrm{kg}$ in silages from the sheath surrounding the heart of peach palms. Neto et al. (2001) studied peach palm silage (stem, leaves, and sheath) with additives $(25.0 \mathrm{~g} / \mathrm{kg}$ sugar, $10 \mathrm{~g} / \mathrm{kg}$ citrus pulp, and $100 \mathrm{~g} / \mathrm{kg}$ cornmeal) and observed $102.0 \mathrm{~g} / \mathrm{kg}$ average CP content; this value was probably caused by the presence of leaves from peach palms in the silage, as well as protein additives.

The observed lignin values for the three silages were relatively high in comparison to some forage plants used in animal feeding because of the advanced age of the Alexander palms (four years) required to produce heart of palm from this species. It is known that sheaths have higher lignin concentration compared to leaves (Table 2) because of the support function of this substance within the plant.

Values of $\mathrm{pH}$ between 3.8 and 4.2 are considered appropriate for well-preserved silages, because plant proteolytic enzymes and enterobacteria are restricted to this range (Tomich et al., 2004), and the sheath and compound silages were close to this range (Table 3). Acidity is considered an important factor in silage preservation because it inhibits or controls the development of harmful microorganisms, such as the bacterial genus Clostridium, which is sensitive to $\mathrm{pH}$ below 4 (Whittenbury et al., 1967).

Oliveira et al. (2010) found $70.7 \mathrm{~g} / \mathrm{kg}$ ammonia nitrogen in wilted peach palm silage. According to Van Soest (1994), low ammonia nitrogen content in the silage, below $100.0 \mathrm{~g} / \mathrm{kg}$ of the total nitrogen, indicates that the fermentation process did not result in an excessive breakdown of proteins into ammonia, and amino acids constitute the largest part of the nonprotein nitrogen. Thus, ammonia nitrogen content higher than $100.0 \mathrm{~g} / \mathrm{kg}$ could represent low quality silage, because the higher the ratio, the more protein has been degraded, and the lower the quality (Jianxin and Jun, 2002). However, all silages displayed ammonia nitrogen contents lower than $100.0 \mathrm{~g} /$ $\mathrm{kg}$ (Table 3), characterizing the silage, from this perspective, as good quality.

The concentration of lactic acid in the silages was higher in relation to the other acids from fermentation. This is a positive factor, because crop residues generally do not present favorable lactic fermentation, and this could impair the final quality of the silage. Despite the contribution of butyric, acetic, and propionic acids to the $\mathrm{pH}$ decrease, lactic acid plays a more efficient role in this process because of its greater dissociation in relation to the other acids (Silva et al., 2011).

The silages with sheath in their composition had higher $(\mathrm{p}<0.05)$ acetic acid content (Table 3$)$ compared to that of leaf silage. Lactic acid bacteria can be homofermentative, i.e., able to produce only lactic acid, whereas the heterofermentative lactic acid bacteria produce lactic and acetic acids (Lopes and Evangelista, 2010). Thus, the silages with higher sheath content likely influenced the development of heterofermentative lactic acid bacteria, increasing the acetic acid content. Acetic acid assists in the aerobic stability of the silage (Danner et al., 2003), thus maintaining its quality. 
Plant residues, usually with low nutritional quality, especially substrates for fermentation, tend to have higher butyric acid content. In addition, despite the low DM content present in the fresh sheath and compound (Table 1), which might benefit butyric acid production, these acids were found at low levels (Table 3).

In conclusion, according to the fermentative parameters, waste from heart-of-palm production using Alexander palms has potential for silage production. However, the differences in the composition of silages at the time of ruminant feeding should be considered, mainly with regard to lignin and protein content.

\section{Acknowledgments}

At Fundação de Amparo à pesquisa do Estado de Minas Gerais (FAPEMIG) for financial support. Thanks to Prof. Carlos Machado for supplying the residue from palm production.

\section{Conflicts of interest}

The authors declare they have no conflicts of interest with regard to the work presented in this report.

\section{References}

Association Of Analytical Chemists - AOAC. Offcial methods of analysis. Washington, DC; 1990.

Australian fodder industry associtation (AFIA). Laboratory Methods Manual. Version 7. Melbourne; 2011.

Bayão GFV, Queiroz AC, Freitas SG, Batalha CDA, Sousa KRS, Pimentel RM, Cardoso LL, Cardoso AJS. Substituição do resíduo da produção de palmito da Palmeira Real Australiana (Archontophoenix alexandrae) na silagem de cana-de-açucar em dietas de ovinos. Arch Lat Nutr 2014; 64: 271-276.

Casali AO, Detmann E, Valadares Filho SC, Pereira JC, Henriques LT, Freitas SG, Paulino MF. Influence of incubation time and particles size on indigestible compounds contents in cattle feeds and feces obtained by in situ procedures. Rev Bras Zootec 2008; 37: 335-342.

Cunniff, P. Association of official analytical chemists - AOAC. Official methods of analysis 16.ed. Arlington: AOAC; 1995.

Danner H, Holzer M, Mayrhuber E, Braun R. Acetic acid increases stability of silage under aerobic condicions. Jour Bacter 2003; 69:562-567.

Fermino MH, Gonçalves RS, Silveira JRP, Battistin A, Trevisan $\mathrm{M}$, Busnello AC. Palm fiber as substrate for vegetables. Hort Bras 2014; 32:404-408.
Figueiredo CC, Ramos MLG, Mcmanus CM, Menezes AM. Mineralização de esterco de ovinos e sua influência na produção de alface. Hort Bras 2012; 30:175-179.

Jianxin L, Jun G. Ensiling crop residues. Animal Production Based on Crop Residues - Chinese Experiences. Food and agriculture organization of the united nations (FAO). Rome, Italy; 2002.

Jobim CC, Pereira Filho JM, Silva AM. Utilização de forragens conservadas na região semiárida do nordeste do Brasil. Sistemas Agrossilvipastoris no Semiárido. Ed. Universitária, Campina Grande; 2009.

Licitra G, Hernandez TM, Van Soest PJ. Standardization of procedures for nitrogen fractionation of ruminant feeds. Anim F Sci Techn 1996; 57: 347-358.

Lopes J, Evangelista AR. Características bromatológicas, fermentativas e população de leveduras de silagens de canadeaçúcar acrescidas de ureia e aditivos absorventes de umidade. Rev Bras Zoot 2010; 39:984-991.

Mertens DR. Gravimetric determination of amylase-treated neutral detergent fiber in feeds with refluxing in beakers or crucibles: collaborative study. Journal of AOAC International 2002; 85: 1217-1240.

Oliveira LS, Pereira LGR, Azevedo JAG, Pedreira MS, Loures DRS, Bomfim MAD, Brito RLL. Nutritional characterization of co-product silages of pejibaye. Rev Bras S Prod Anim 2010; 11: 426-43.

Rodrigues Neto AJ, Bergamaschine AF, Isepon OJ, Alves JB, Hernandez FBT, Macedo MP. Effect of Additives on Nutritive Value of Silages Based on Palm Cabbage Production By-products from Pupunha (Bactris gasipaes). Rev Bras Zootec, Viçosa 2001; 30:1367-1375.

Schmidt P, Junior PR, Toledo LM, Nussio LG, Santiado AD, Meduri B. Fermentative losses and chemical composition of pupunha palm by-products ensiled with chemical additives. Revis Bras Zootec 2010; 39: 262-267.

Santos EM, Zanine AM. Silagem de gramíneas tropicais. Colloq Agrar 2006; 2:32-45.

SAS $^{\circledR}$, Statistical Analysis System. SAS/STAT User's Guide. Version 9.2. Cary (NC): SAS Institute Inc., 2008.

Silva JB, Reis ST, Rocha Júnior VR, Sales ECJ, Mota, VFG, Jayme DG, Souza VM. Características fermentativas da silagem do capim Marandu manejado em diferentes alturas de dossel. Reb Bras Saúde Prod An 2011; 12:329-339.

Tomich TR, Rodrigues JAS, Tomich RGP, Gonçalves LC, Borges I, Rodriguez NM, Campos MM. Forage potential of six sorghumsudangrass hybrids. Arq Bras Med Vet Zootec 2004; 56:258-263.

Van Soest, PJ. Nutritional ecology of the ruminant. 2nd ed. Ithaca: Cornell University Press; 1994.

Whittenbury R, Mcdonald P, Bryan-Jones DJ. A short review of some biochemical and microbiological aspects of silage. J sci Food Agric 1967;18:441-444.

Wilson, RKA. A rapid accurate method for measuring volatile fatty acids and lactic acid in silage. Agricultural Institute, Dunsinea Research Centre. (Research Report); 1971. 